\title{
Quality issues: Beyond the Nigerian institution
}

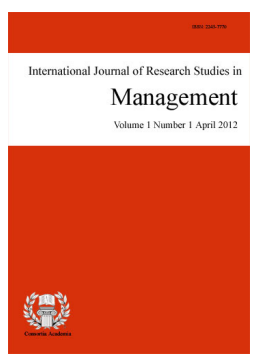

\section{Abstract}

The article aims to take a step back to look at the issue of quality in Nigerian universities and identify those factors that have adverse effects on the process of establishing quality in universities but that cannot be controlled by the institutions' principal officers. This paper reviewed the relevant literature using a standard literature review and found the opinions of 36 principal officers in six Nigerian universities regarding issues that affect quality but that are beyond the institutions' control. The findings suggest that finance is not the only issue of this type. It was observed that external issues play vital roles in the administration and delivery of university services. The study concluded by discussing issues that would not be considered in other countries as matters for concern but that have an impact beyond what principal officers can control in the Nigerian context.

Keywords: quality; principal officers; university; Nigeria 


\section{Quality issues: Beyond the Nigerian institution}

\section{Introduction}

When discussing the issue of quality in higher education, and universities in particular, the first point to keep in mind is that the education sector does not function or operate like other sectors, such as the manufacturing, communication, industrial or service sectors. This is because all these sectors deal with the production of objects (irrational) that can be used to improve rationale feelings, experiences, or emotions, thus making it easy to evaluate issues of quality based on what can be seen, touched, or felt. This also makes it easier to suggest techniques or approaches that can be quantified through the use of codes, assigned to a system function, and so on. However, in universities, the students cannot be subjected to total quantification, as opposed to products in other sectors, because while quality of education can experience added value during the education process, it cannot be felt, seen, or touched. Thus, while different mechanisms have been used to evaluate quality in different sectors, none of these has been suggested as being an appropriate solution for how to measure quality in and education, and especially a university context.

In the university context, many conflicting voices have been raised to address this issue; academics have considered approaches such as standards, benchmarking, good practice, and many more as there is a desperate need to bring about changes in the administration of universities. This is true in Nigeria in particular, "where stakeholders' demand for quality has continued to increase daily as a result of intensifying and diversifying programs for the development of high level manpower within the context of the needs of the nation' (Adeogun \& Osifila, 2010, p. 45). A few researchers who have studied the quality of education in Nigeria (Ibukun, 1997; Mgbekem, 2004; Ajayi \& Ekundayo, 2008; Obasi, Akuchie, \& Obasi 2010) have suggested that focusing on quality issues or university problems alone will not help the institutions, but claim instead that there is need to identify problems, and that to find solutions to how best to improve the quality in the context of Nigerian universities, for example, it is necessary to look beyond getting accreditation or funding from the National University Commission (NUC) or the government through the federal/state Ministry of Education alone. In a conclusive study, Adeogun and Osifila suggested that research activities may be the best way to readdress financial issues through foreign government education aids, grants from Non-Governmental Organizations (NGOs) and support from international bodies or agencies.

Considering the above issues, it is crucial that universities start looking beyond what the government can do for them and start thinking of what they can do to improve their professional practices as well as the institution. This approach can help explain the position of the quality issue in the Nigerian university context. Therefore, it is important to look beyond what can be measured as an event.

\section{Quality Issue}

In the little research work that has focused on university education in Nigeria (Adelabu \& Akinwumi, 2008, Salmin, 2001; 2009; Ogundare, 2009; Obasi, Akuchie, \& Obasi 2010), researchers have used a quantitative approach. These researchers have suggested that Nigerian universities have been involved in the quest for quality since 1934. This was evident in the findings represented by Fafuwa (2004) in his book 'History of Education in Nigeria'. He reported that 1934 marked the beginning of Education Colleges in Nigeria; he pointed out that the University College of Ibadan was the first university in the country, but was advised by the Ashby committee not to award its own degrees. Instead, the committee advised the university to allow the University of London to conduct and monitor its examinations until it was recognized as a fully-fledged university. This was as a result of the high demand for quality education in the country. However, as Ajayi (1997) reported, the Nigerian government during this period ignored the advice of the Ashby committee. As a result, another commission was set up in 1962 to look into the development and need for university education in the next ten years. 
The report of commission was the first controversy regarding the quality issue in the history of Nigeria university education. The commission had a disagreement, which led to two different reports being published. Fafunwa (1971) explained that the commission's first report advised the Federal Government of Nigeria to create more universities while the second report objected to the Nigerian government creating its own universities due to small enrolment in the university college of Ibadan at that time. However, the Nigerian government decided to ignore the two reports from the commission, and instead created universities based on political regions. This gave rise to the first major problem of education in the country, because the universities found it difficult to attract enough students. However, before the end of 1965, the demand for university education had increased and indeed exceeded the projection of the commission; nonetheless, the government did not do anything to improve the quality of the universities or to meet this demand. Nevertheless, quality first appeared on the agenda of the Nigerian government with the suggestion that the colleges that had been created should be run as an affiliation of the University of London, thus showing that the demand for quality education in the country was as old as the establishment of the first university.

In the same vein, Ibukun (1997) revealed that in 1979, the country witnessed the establishment of the first private universities. Twenty-six private universities were lawfully established but a major issue in their formulation was that they were wrongly constituted with no academic-minded personnel on the board of trustees or in their formation, and there was no proper arrangement for lecture facilities, something which the Nigerian government realized would jeopardize the quality of teaching, learning, and research, thus leading to possible crises in the future. As a result, the government dissolved the universities and placed a ban on establishing private universities in the country. It is interesting that knowingly or unknowingly, approaches and measures have been taken to maintain how the universities are formulated, an approach which can be linked to quality assurance in the country.

Another interesting landmark achievement in an attempt to improve the quality of education in Nigeria was the establishment of the office Minister of Education in the three main regions. Fafunwa (1971) reported that in 1969, each region's Minister of Education became the key policy formulator of his or her region's education with Lord Lugard introducing a two-policy system that involved both direct and indirect rules. Direct rules were introduced in the western part of the country, which restricted Christianity and western education but promoted the Islamic religion, and established a flexible system of education in the north of the country. This approach was assumed to be a major setback as it did not use a common platform for access to education in Nigeria. Likewise, this was assumed to be the one of major reasons why those in the north of the country do not engage well in learning and development. Consequently, the Nigerian government has been trying to engage those in the north of the country in the education system by introducing catchment and non-catchment areas. A catchment area is a scheme for a particular area where there is a strict policy on education criteria while non-catchment areas enjoy a flexible policy. Again, this was seen as a major setback as there was no common platform to assess education provision in the country.

Another major concern identified in the study of Nigerian university education was the regular change in office of the political administrator, which led to a huge mismanagement in the administration and implementation of government policies in the country. Several researchers, such as Ojerinde (2008); Aina (2010), stated that between 1991 to 1998 , Nigeria as a whole experienced eight political leaders, and in each term of office, a different Education Minister was chosen with each introducing a different system, techniques, or policies that were then implemented irrespective of whether they were appropriate or whether they functioned properly. This caused a lot of confusion for principal officers, who had to manage the operation of the universities, and led to much confusion regarding what policy or technique they should follow. Today, these power shifts are seen as another major problem that has affected both the country's economy and its education system.

It was also observed by Ajayi (1997) that at the beginning of education in the country, university academics who were well known for their research work and creativity were well supported by the government, but as soon 
as the period of instability regarding the public office holders began, it became difficult for academics to carry out research work in the country, because there was a lack of the necessary facilities and of the funding required to update the present technologies; nor were there sufficient funds to carry out research work in the existing universities. In order to rectify these problems, the principal officers in the universities embarked on continuous strike action via different internal stakeholders, such as Academic Staff Union of Universities (ASUU), Non-Academic Staff Union of Universities (NASUU), and even students as a sign of the desperate need to bring about radical change in the provision of education. The action by the ASUU blamed the government for ignoring the issue of quality. Likewise, Adesina (2005) pointed out that on many occasions, this group of stakeholders had called on the government to provide them with the facilities and equipment they needed to do their job and discharge their duties effectively. However, when government failed to respond to the demand, they embarked on strike action to emphasize their demand for change. Therefore, it is evident that the manner in which the universities have been operating in the last two decades has been a cause of concern for all stakeholders.

Adesina (2005) also pointed out that the quality of education in the country is affected by the continuous demand for university education without there being any universal access; this was as a result of the failure to make provision for university education, as earlier suggested by the commission's report in 1962, which recommended that the Nigerian government should make provision for the establishment of more universities, but which was not adopted properly (Fafunwa 1971; Ajayi 1997). One important step the government recently took to meet this demand was to create more university access. Nigerian government has viewed access as a way to improve the system, though many assumed this to be a political campaign tool in order to get into office, after which they fail to create meaningful access for learning and those they created are lacking the right choice of equipment that can fit into the contemporary development of education. In the process of creating access, the universities have lost their value of facilitating knowledge to educate and of adding value to student knowledge, as many universities now admit more students to meet the running costs, meaning there are fewer academic staff to cater for a greater number of students. In some cases, the student-to-teacher ratio has been compromised with massive increases in the number of students in a lecture theatre where a lecturer teaches from 250 to 1500 students without the necessary facilities for this, such as no graduate assistant to help, and indeed, in some cases, the graduate/teaching assistants are employed to do the job of lecturers. On other occasions, there are no microphones or projectors, there is no one-to-one contact between students and their lecturers, and other teaching aids intended to make the exercise meaningful are obsolete. Student knowledge is tested by what they can memories and not by what they know or what they can do. Therefore, resolving quality issues in the Nigerian university education sector has become a major issue, which is difficult to resolve when the situation is compared to that of other universities across world.

\section{Research Methodology}

This paper gathered practical evidence from principal officers using six Nigerian universities (three public and three private). A purposive sampling technique was used to select the six universities studied. In accordance with the research aims, this paper chose to interview higher executive officers in each university, such as vice-chancellor, registrar, bursar, director of academic planning, and dean of faculty; they are known as top executive officers and are sometimes referred to as the management as they are involved in the day-to-day administration of the university. A qualitative approach was suggested to fill the gap identify in the literature. An approach that many study of this nature will not consider, rather they will focus on what to measure. This intension has made them to adopt a quantitative approach to their studies. This paper collects information from using a qualitative approach. Therefore, the data presented in this paper were collected from university management with each principal officer involved having at least 15 years of work experience. Their position in the university and the roles, responsibilities, and duties they performed was the key reason for their selection for this study. This selection method was ideal as it was important to obtain very rich data from those who understand and are involved in the quality-based decisions of the university. However, the data from the survey are limited in that the survey covers only issues related to factors affecting the quality of Nigerian universities 
that are beyond their institutional control. There are no existing data on factors affecting the quality of Nigerian universities beyond their institutional control especially as related to the issue of quality. The opinions of the 36 participants who took part in the study were very strong as they were top-level academics; thus, their involvement in quality issues made their views relevant to the study.

In this paper the selection of those involved in the activities of the university increases the authenticity of the findings presented. The presentation of data relating to factors affecting quality issues beyond institutional control in Nigeria also increases the authenticity of the study, while principal officers' daily duties and position of authority in the university is assumed to increase the trustworthiness of the findings. It was also assumed that the problems faced by Nigerian universities could not be understood unless those who are involved in the running of the daily activities of the institution are interrogated, hence making it difficult to replicate the approach or approaches developed from another environment in Nigeria (Adetunji, 2014). The findings were analyzed and discussed using descriptive analysis. This paper does not claim that the findings can be generalized to other institutions outside Nigeria but does claims the generalizability of the six universities that were studied within Nigeria.

\section{Table 1}

Participant's grid

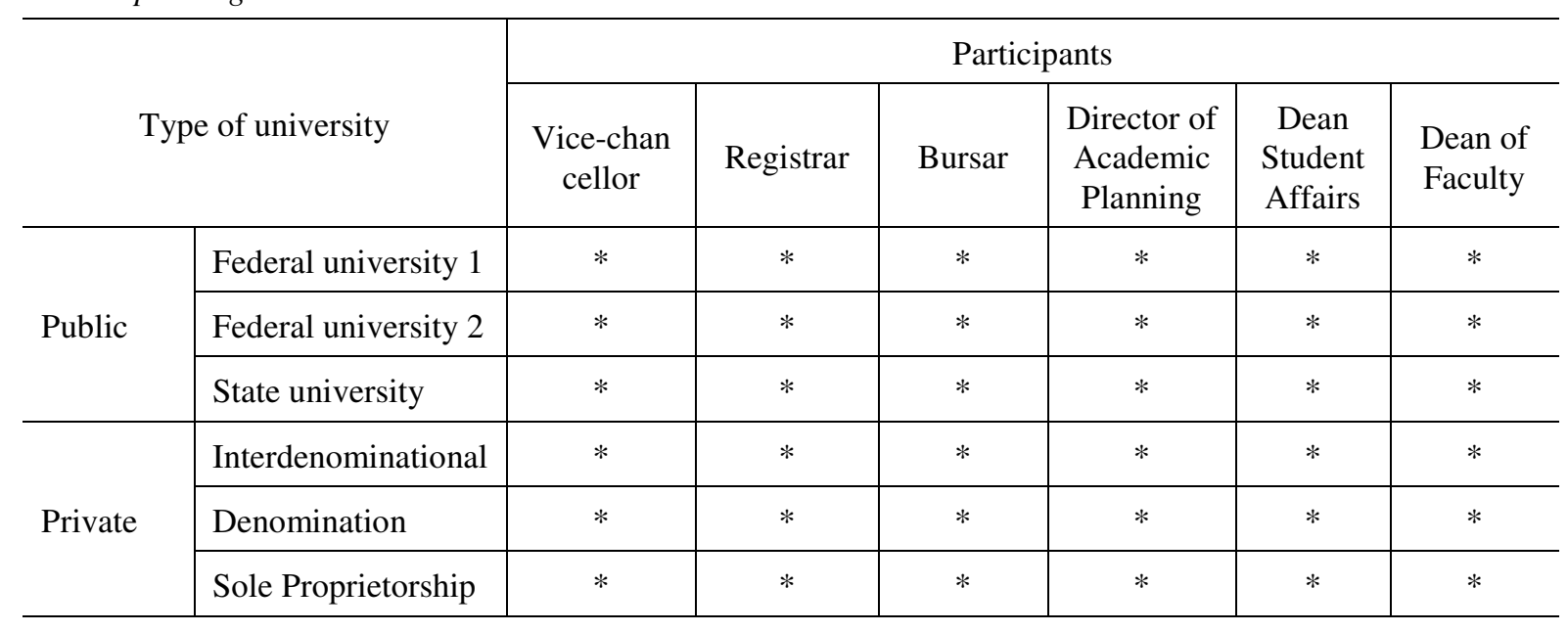

The first criteria used to arrange the universities selected for this study was their period/year of establishment. Public universities were allocated A-C, while private universities were allocated D-F. Thus A = federal university, $\mathrm{B}=$ federal university, $\mathrm{C}=$ state university, $\mathrm{D}=$ interdenominational university, $\mathrm{E}=$ denominational university, $\mathrm{F}=$ sole proprietorship university. 1 = vice-chancellor, 2 = registrar, 3 = bursar, $4=$ director of academic planning, $5=6=$ dean of faculty. Therefore A1 is the vice-chancellor from federal university 1, B1 is the vice-chancellor from federal university 2, F1 is the vice-chancellor from the sole proprietorship university, A6 is dean of faculty from federal university 1, B6 is dean of faculty from federal university 2, G6 is dean of faculty from the sole proprietorship university.

\section{Factors Affecting Nigerian University Qualities that are Beyond the Institutions' Control}

The 36 respondents shared a common view on three major factors that they claimed have a strong impact on overall performance: the power supply, the quality of the families in the community, and the quality of primary and secondary school the students attended.

\subsection{Power supply}

All respondents mentioned at one point or another that a disrupted power supply affected their university performance in many ways. One of the respondents elucidated that "if you want to have quality 
Adetunji, A. T.

teaching/meaningful research and there is an erratic power supply, you will not be able to concentrate on the research that you are doing" (vice-chancellor). Another participant added, "In a situation where you have to test for a result in the laboratory and you have low power supply, the technology you are using may give you a poor result or may not even work at all" (director of academic). Sixteen participants also condemned the administration of the power supply in the country. They mentioned that the poor effort in administrating the power supply affected all parts of the business sector in the country. They explained that the Power Holding Company (PHC) gives them a bill they need to pay every month, whether or not they have supplied the university with power. They argued that the amounts charged are not justified but that there is no law to check their dealings since they are government agency. Five of the respondents lamented that the amount of money their institution had been forced to invest in running a generator would have been sufficient to develop other aspects of learning, as is the case in other countries where they are not worried about power. They emphasized that power issues cannot be allowed to compromise the activities of the university, and that is why they have had to invest in alternative and far more expensive ways to generate power. One of the participants (Vice-chancellor) explained:

\section{I think we need electricity to run our computers, to carry out our Computer Based Examinations $(C B E)$. I cannot rely on PHC to supply power throughout the day when the CBE is going on. It is difficult for us to use power supplies by the PHC: because the power can fail at any time and all the computer will shut down which will affect the exam process, students will lose their information and will have to start again. Therefore, we prefer to use generators for the period of the examination which costs the university more. (C1)}

Thirteen of the informants were questioned further about why Nigerians are still suffering from an unreliable power supply and a lack of good roads when Nigerian universities have been producing graduates in mechanical, electrical, and civil engineering since 1964. Four of the participants elucidated that many Nigerian graduates have passed through the university education system not because they want to contribute to the development of the nation, but because they want to get a degree in order to secure a white-collar job. Again, it was mentioned by two participants, as a way to justify the poor performance of graduates in the community, that many of these graduates have good intentions to develop the nation, but the major problem is that without a power supply, nothing can be done. In addition, one of the participants pointed out,

In an instance where we are talking about getting students involved in their learning as well as encouraging them to do better, there is no power supply to power electrical materials to ventilate the reading room or the library: even the environment in which students receive lectures is not good. All these will have an effect on quality, especially quality of transformation. (B5)

A comparison of any Nigerian university with any university in a country that does not have to worry about the power supply would clearly indicate that the outcome of performance for both teacher and learners cannot be the same. Thus, it is not surprising that twenty of the participants complained that it was very difficult for them to perform any practical activities that could engage the students. Five of the participants commented that organizations that were supposed to value their activities were not willing to invest in education because they believed the return on such an investment would be low as there is the risk that students may not be taught well. Furthermore, nine of the participants claimed that as universities are a government agency and an agent of national development, they should not be charged the same for power as are other sectors who are profit-making organizations.

It was implied that in most cases, universities pay more than other sectors for power. Eleven participants were even more concerned with the incorrect voltage input from the PHC, which could damage their apparatus. One of the participants gave the example of how the power packs of 56 computers were burned in one minute. He explained that it had taken his department two years to raise funds for the computers, but in just one minute, they had lost all the computers due to the wrong power voltage. His frustration was that no compensation was 
received from the PHC nor even any apology for what they have done was clear.

\subsection{Quality of the family in the community}

Twenty-two respondents placed serious emphasis on the home and community the student comes from as a factor beyond the university's control. Six of the informants explained that many students cannot cope at university as a result of family problems that affect their ability to respond well in the classroom. A few informants talked about students' family background; they mentioned, for example, that in a situation where the husband abuses his wife in front of the children before they leave home for school in the morning and refuses to give the children money for school, such students will be focusing on those emotions even in the classroom, rather than concentrating on the class activities. However, one of the participants (Vice-chancellors) added:

Regarding the academic staff, like every human being, you find some bad ones who are not doing their job properly - for example, collecting money to pass students or having sex with them in return for marks - and again, these are coming from the society. (C1)

This type of behavior is a component of the society; indeed, the participant claimed that they had frequently witnessed parents giving money to lecturers as a financial inducement to guarantee their child's success. Another issue is that of corruption, whereby students want to pass at all costs. Furthermore, a participant (dean of faculty) mentioned:

I would also add that, when we talk of the society, parents must be involved because a lot of students are distracted right from home. Some parents want their children to study a course that does not interest the students themselves. These are major concerns for the institution. (D6)

Nineteen of the respondents claimed that family background plays a vital role in the life of the student. They mentioned that some students are willing to study, but the families they come from cannot even afford to feed them, let alone pay their school fees. They claimed that poor funding cannot be blamed $100 \%$ on the government. Likewise, one of the participants commented that parents also have their own responsibility for maintaining students by providing them with living expenses. This situation should be compared to the United Kingdom, for example, where students are in control of their fees having secured a loan from the government to follow the program of their choice.

Likewise, one participant added that apart from financial responsibilities, parents also encourage students by bribing their way to obtain good GCSE results for their children. Fourteen of the participants expressed their concern that some students arrive at university with very high marks, but while the only basis for admitting candidates is to use their obtained grades, there is no guarantee about how they got them. How can you explain it if a graduate finishes university, yet when he goes for an interview, he cannot express himself? Eighteen of the participants agreed that student indiscipline stems from the society, because the students are the heartbeat of society: "We have students from various backgrounds here and the society has affected many students' behavior, maybe from home. Some lack guidance or parental care: hence, when such students come to university, it reflects in their way of life." This can frequently be seen in the behavior of the students, especially in the private universities.

\subsection{Quality of primary and secondary schools}

Twenty-nine of the participants talked about the quality of pre-university education as a factor that affects students and that is beyond the universities' control. Twenty-three of these participants revealed that a number of students from public primary and secondary schools do not perform well at university. Their opinion was that there are many factors that are responsible for this poor performance, among which they mentioned funding. Indeed, six of the participants supported this view by adding that frequently, primary and secondary teachers' salaries are delayed or not paid for five to six months. As a result, many primary and secondary school teachers 
Adetunji, A. T.

now commit themselves to trading as a second job and are thus unable to devote adequate time and attention to lesson planning, innovative teaching, or further research. Another participant (dean of faculty) who supported this assertion, stated:

Primary and secondary schools should be learning places, where teachers should support pupils to discover their potential and guide them to fulfil their dreams. But that is not the case. Take, for example, myself: I was forced to enroll in science class when I was in secondary school but I ended up studying accounting in the university as my chosen career. If I had been allowed to make a choice earlier I might, of course, be better than I am now. (G6)

Five other participants raised the issue of overcrowding, non-conducive environments for learning, a lack of student-centered learning, the maltreatment of pupils, unnecessary discipline that can affect pupils' concentration in class, and many more. These are issues that have been translated into student life and that the university cannot control. Eight of the participants argued that even if the environment is not conducive and pupils are taught in a dilapidated building, if teachers focus their attention on learners, they will still perform better if they are motivated to read and take responsibility for their own learning. However, 14 of the participants added that it was difficult to achieve good practices because the teachers are very lazy; they also struggle because they have not had good teacher training, but have selected teaching jobs as a means of earning a livelihood.

Fifteen of the participants summed up these challenges and questioned the output of such training; they stated that it is difficult to ascertain whether the grades assigned to pupils are as a result of their good work or whether they are a quality output, and indeed, it is not known until the students enter the university system for further or advanced transformation. Therefore, if quality is to be achieved, there is a need to know how best to fit students into the university. Six of the participants emphasized that quality should be a focus from the primary school level, because without a very good foundation at the start, then everything will be difficult. Similarly, four of the respondents argued that graduates from primary and secondary schools are the input of university while eight participants explained that if there are faults in the level of transformation at both primary and secondary school, it will reflect in the life of such students at university. Therefore, they believed that the quality of university education should be tested right from primary school up to the university level, and quality should be measured and discussed.

\section{Conclusion}

This paper has acknowledged the factors affecting the functionality of Nigerian universities beyond the control of the principal officers. The study has acquired great importance as factors identified therein will not have been appreciated without this research, in view of the fact that there are few factors that have an immediate impact on the running of the university in a real sense. It is obvious that even when demand for quality arises within the university, the principal officers always do their best to resolve any problems. This study has identified that when issues are beyond institutional control, then it is hard for the principal officers to resolve such problems. It is clear that Nigerian university principal officers are doing extremely well under these very difficult circumstances by keeping the sector running despite the vast number of quality issues identified in the study. Nonetheless, in an idea environment, it is the duty of the principal officers to ensure the smooth running of the university system.

\subsection{Practical Implication and Limitations}

This study has contributed to the enlightenment of both internal and external stakeholders regarding what exactly are the problems of Nigerian universities by looking at things that are not considered by other institutions to be a problem when managing or determining quality. This short piece of research is expected to inform researchers, institutions, professionals, parents and even students about things they need to be aware of in their institution. Likewise, the study has expanded our knowledge of things that are beyond the institution's control. 
This knowledge can help the institution to be more focused and work towards eliminating these problems. In addition, this study has exposed the untouched area of the sector to the government agencies who should take responsibility for correcting the wrongs landed at their feet if they want Nigerian universities to compete with their counterparts overseas. This paper did not discuss other factors suggested by the respondents, where $50 \%$ of the respondents were not in agreement regarding the factors affecting their performance. This approach was used to focus solely on the research objective of this paper, which is to examine the origin of the quality problems in Nigerian universities and understand what factors have adverse effects on university quality process but cannot be controlled by the institutions' principal officers.

The focus of this paper is solely on factors that affect principal officers but that is beyond their control. In other words, it does not mean that the three factors discussed here are the only factors affecting principal officers' performance in Nigerian universities, but this paper considers these three factors as crucial as they were comprehensively suggested by the 36 participants. Likewise, given that the study is limited to 36 participants, generalization of such factors and the application of the findings should be considered with care. Again, the paper does not claim that if these three factors were removed or dealt with, the principal officers could be motivated to perform better. This is because performance is subject to many entities and some of these can be examined in a future study. The study is limited in that it does not suggest any ways to remove these impeding factors from the university operations; nor does the paper take into account quality issues other than the ones discussed in this paper.

\subsection{Significant contribution}

This paper examines quality issues in Nigerian universities from the principal officers' perspective and looks beyond quality on the surface. Researchers in the field of quality management have studied quality with the intension to measure quality as if it could be quantified. Scholars with this belief and approach normally adopt positivist approach to their research with the intension of using a questionnaire or structured interview to gather information. They always describe quality as if it can be measured in meaningful terms. This paper adopts a different approach by studying quality issues in the university, looking beyond what is measurable, an approach not found in literature at present. This paper is relevant to the needs of universities in general and to those of Nigerian universities in particular as the institution continues to make different attempts to improve its operation and make the student experience better. Another new dimension in the way this paper has addressed the issue is the approach the study took to view factors affecting quality beyond institutional control while other studies of this nature focus on what the problems are and what possible solutions can be suggested to solve them. This approach to studying quality only looks at the problem on the surface. Likewise, in the past, the literature has attempted to look at university quality as a borrowed approach to management while this paper considers quality as part of the institutional function.

Given the case of university education in Nigeria, it will be difficult for students and academic staff to function effectively. While this does not mean that theoretical knowledge will not be passed on to students, the situation will eventually affect staff development, and students will receive obsolete knowledge rather than the updated information that can equip them for the future.

\section{References}

Adelabu, M. A., \& Akinwumi, F. S. (2008). Factors affecting academic quality in Nigerian universities. Journal of the World Universities Forum, 1(5), 47-61.

Adeogun, A. A., \& Gboyega G. I. (2010). Declining quality of Nigerian university graduates: Revitalizing quality assurance through foreign agencies' support. US-China Education Review, 7(6), 45-53.

Adesina, S. (2002). The development of modern education in Nigeria. Heinemann Education Books, Ibadan.

Adetunji, N. (2014). Government policies in relation to quality management implementation: A Review of Nigerian universities principal officers. Journal of Organisational Studies and Innovation, 1(1), 22-34. 
Adetunji, A. T.

Adetunji, A. T. (2014). A critical realist study of quality management in Nigerian universities. Unpublished doctoral dissertation, Cardiff Metropolitan University, South Wales, United Kingdom.

Aina, O. I. (2007). Alternative modes of financing Higher education in Nigeria and implications for university governance. In J. B. Babalola \& B. O. Emunemu (Eds.) Issues in higher education: Research evidence from sub-Saharan African. Lagos: Bolabay Publications.

Ajadi, T. O. (2010). Private universities in Nigeria - the challenges ahead. American Journal of Scientific Research, 7, 15-24.

Ajayi, I. A., \& Ekundayo, H. T. (2008). The deregulation of university education in Nigeria: Implications for quality assurance. Nebula, 54, 212-224.

Ajayi, T. (1997). Maintenance of academic standards in Nigerian schools. Some basic planning consideration. In A. M. Ejiogu \& K. Ajayi (Eds.), Emergent issues in Nigerian education (pp. 184-194). Lagos, Unilag Consult.

Fafunwa, A. B. (2004). History of education in Nigeria. Ibadan: NPC Educational Publishers Ltd.

Federal Military Government. (1974). Decree No. 1 Establishing National Universities Commission Supplement of Official Gazett.

Federal Republic of Nigeria. (2004). National Policy on Education. Lagos: NERDC.

Gabor, A. (1992). The man who discovered quality: How W. Edwards Deming brought the quality revolution to America. New York, NY: Pengiun.

Ibukun, W. O. (1997). Educational management: theory and practice. Ado-Ekiti: Green Line Publishers.

Mgbekem, S. J. A. (2004). Management of university education in Nigeria. Calabar: UNICAL Press.

Obasi, I. N., Akuchie, R. C., \& Obasi, S. N. (2010). Expansion of higher education access through private universities in Nigeria (1999-2009): A decade of public policy failure. Paper presented at a National Conference on Education for Nation Building and Global Competitiveness, organized by NERDC at the International Conference Centre, Abuja.

Ogundare, S. F. (2009). Teacher Education and the challenges of Global Economic meltdown. Paper presented at the 2nd National Conference of Emmanuel Alayamde College of Education, Oyo.

Ojerinde, D. (2010). Unified Tertiary Matriculation Examination (UTME): Prospect and challenges. Paper presented at the National Education Conference, Nigeria.

Salmi, J. (2001). Tertiary education in the 21st century: challenges and opportunities. Higher Education Management, 13(2), 105-129.

Salmin, J. (2009). The challenge of establishing world-class universities. World Bank Publications. http://dx.doi.org/10.1596/978-0-8213-7865-6 